\title{
Occurrence of Hydroxypyruvate-L-Glutamate
} Transaminase in Escherichia coli and Its Separation from HydroxypyruvatePhosphate-L-Glutamate Transaminase

\author{
L. BLATT, F. E. DORER, AND H. J. SALLACH \\ Department of Physiological Chemistry, University of Wisconsin Medical School, Madison, Wisconsin
}

Received for publication 16 May 1966

\begin{abstract}
Blatt, L. (University of Wisconsin, Madison), F. E. DoRer, aND H. J. Sallach. Occurrence of hydroxypyruvate-L-glutamate transaminase in Escherichia coli and its separation from hydroxypyruvate-phosphate-L-glutamate transaminase. J. Bacteriol. 92:668-675. 1966.-The formation of L-serine from hydroxypyruvate by a transamination reaction with L-glutamate has been demonstrated in extracts of Escherichia coli. The level of activity with hydroxypyruvate is approximately one-tenth that observed with hydroxypyruvate-phosphate in cell-free extracts. The transamination of hydroxypyruvate, but not hydroxypyruvate-phosphate, is inhibited by inorganic phosphate. No marked differences in the levels of activity with hydroxypyruvate were observed in extracts from bacteria grown under different conditions. Heat treatment of enzyme preparations at $65 \mathrm{C}$ rapidly destroys the activity with hydroxypyruvate-phosphate, but not that with hydroxypyruvate. Fractionation of extracts with lithium sulfate and alumina $\mathbf{C} \gamma$ resulted not only in a 10-fold purification, but also in a complete separation of the two activities, thereby establishing that two different enzymes are involved in the transamination of hydroxypyruvate and hydroxypyruvate-phosphate. Hydroxypyruvate transaminase is present in two mutants that require serine for growth. The inability of hydroxypyruvate to replace the growth requirement for serine, even to $a$ limited extent, was shown to be due to the inability of the bacteria to accumulate this compound actively.
\end{abstract}

The transamination of hydroxypyruvate-phosphate with L-glutamate to yield serine-phosphate has recently been established as one step in a major biosynthetic route from glucose to serine in Escherichia coli $(15,20)$. The individual steps in the conversion of glycolytic intermediates to serine are: D-3-phosphoglycerate $\leftrightarrow$ hydroxypyruvate-phosphate $\leftrightarrow$ serine-phosphate $\rightarrow$ serine. The reactions are catalyzed by a specific dehydrogenase, transaminase, and phosphatase, respectively. This route for serine formation has been designated as the phosphorylated pathway and has been demonstrated in animal (9) and plant (6) tissues as well. Since mutants of $E$. coli that lack D-3-phosphoglycerate dehydrogenase have a growth requirement for serine, this orga- nism is dependent upon the phosphorylated pathway for serine biosynthesis (20).

The transamination of hydroxypyruvate with L-alanine to yield serine has been demonstrated in animal (18) and plant (23) systems and is one reaction in a second route for serine biosynthesis via the nonphosphorylated pathway (22). The individual reactions in this sequence are: Dglycerate $\leftrightarrow$ hydroxypyruvate $\leftrightarrow$ serine. All of the enzymatic steps for this pathway were demonstrated by Large and Quayle (10) in extracts of Pseudomonas AM1 grown on $\mathrm{C}_{1}$ compounds. In a brief communication, Smith et al. (Bacteriol. Proc., p. 107, 1956) reported that extracts of $E$. coli, Crook's strain, contain the transaminase and serine-phosphate phosphatase of the phos- 
phorylated pathway and the D-glycerate dehydrogenase of the nonphosphorylated pathway.

The present studies show that extracts of $E$. coli catalyze not only the transamination of hydroxypyruvate-phosphate with L-glutamate, but also that of hydroxypyruvate to a lesser, but still significant, extent. Data are presented which establish that the above reactions are catalyzed by two different transaminases.

\section{Materials and Methods}

Substrates, coenzymes, and enzymes. The lithium salt of hydroxypyruvate was synthesized by the method of Dickens and Williamson (4) and was assayed spectrophotometrically with reduced nicotinamide adenine dinucleotide $\left(\mathrm{NADH}_{2}\right)$ and $\mathrm{D}$ glycerate dehydrogenase isolated from spinach leaves (8). L-Serine-phosphate was prepared by the procedure of Neuhaus and Korkes (14). The dimethylketal of hydroxypyruvate-phosphate (Calbiochem) was converted to the free acid as outlined by Ballou (1) and was assayed spectrophotometrically with $\mathrm{NADH}_{2}$ and avian D-3-phosphoglycerate dehydrogenase (21). Other amino acids and $\alpha$-ketoglutarate were commercial preparations. All substrates were neutralized to pH 7.0 before use. The synthesis of 3-C $\mathbf{C}^{4}$-hydroxypyruvate was carried out as described earlier (7). Uniformly labeled $C^{14}$-L-serine was obtained from Volk Radiochemical Co., Burbank, Calif. Glutamate dehydrogenase and alkaline phosphatase, calf mucosa type I (Sigma Chemical Co., St. Louis, Mo.), pyridoxal phosphate (Calbiochem), and nucleotides (P-L Laboratories) came from the commercial sources indicated.

Bacterial strains. A culture of the $E$. coli $\mathrm{K}-12$ used in these studies was obtained from $R$. $L$. Metzenberg of this department. The mutant strains of $E$. coli K-12, strains $S$ and $S / G$, were obtained from $S$. Simmonds of Yale University. These serine-glycine auxotrophs grow on a glucose-salts medium supplemented with L-serine (strain S) or L-serine or glycine (strain S/G). Biochemical studies and genetic analysis have shown that these two strains have the same lesion in the biosynthetic pathway from glucose to serine, namely, the loss of phosphoglycerate dehydrogenase. In addition, strain $\mathbf{S}$ has a second block in the mechanism for the transport of exogenous glycine into the cells (11).

Media and growth conditions. Three different synthetic media were used during the course of this investigation. Medium A contained the following, per liter: $\mathrm{Na}_{2} \mathrm{HPO}_{4} \cdot 7 \mathrm{H}_{2} \mathrm{O}, 36 \mathrm{~g} ; \mathrm{KH}_{2} \mathrm{PO}_{4}, 5 \mathrm{~g} ;\left(\mathrm{NH}_{4}\right)_{2} \mathrm{SO}_{4}$, $3 \mathrm{~g}$; sodium citrate, $3 \mathrm{~g}$; $\mathrm{MgSO}_{4} \cdot 7 \mathrm{H}_{2} \mathrm{O}, 200 \mathrm{mg}$; $\mathrm{CaCl}_{2} \cdot \mathrm{H}_{2} \mathrm{O}, 3 \mathrm{mg}$; FeSO $\cdot 7 \mathrm{H}_{2} \mathrm{O}, 5 \mathrm{mg}$; glucose, $10 \mathrm{~g}$. This medium was used in the experiments referred to in the text as high phosphate growth conditions. For studies with low levels of phosphate, the defined medium described by Garen and Levinthal (5), with $1.6 \times 10^{-3} \mathrm{M} \mathrm{KH}_{2} \mathrm{PO}_{4}$ replacing the peptone (Difco) and sodium glycerol-phosphate, was employed. The minimal medium of Davis (3) with glucose or other carbon sources was utilized in other aspects of this work. In each case, the carbon source was autoclaved separately and was added to the sterile salts solution.
The mutant strains were grown on Davis minimal medium supplemented with either L-serine or glycine at a concentration of $3 \mu$ moles per ml. The ability of strain S/G to grow on D-glycerate or hydroxypyruvate was tested in the presence and absence of serine to determine whether toxic products were formed from the two former compounds. In fact, it was established that hydroxypyruvate did decompose at $37 \mathrm{C}$ and at pH 7.4 to yield products which were toxic to the bacteria. Therefore, these studies were carried out at $25 \mathrm{C}$ and $\mathrm{pH} 6.5$, under which conditions cultures containing serine and either of the above two compounds grew well.

In the initial studies, or when different nutritional conditions were investigated, the bacteria were grown in 4-liter flasks in 1 liter of medium. The cells were incubated, with shaking, at $37 \mathrm{C}$ in a New Brunswick incubator and were harvested in the $\log$ phase of growth. For growth studies, bacteria were grown in 125-ml De Long flasks with side arms suitable for turbidimetric measurements in a Coleman Universal spectrophotometer. Growth was followed by measuring the optical density (OD) at $650 \mathrm{~m} \mu$.

In later studies, to obtain sufficient quantities of material with which to work, the bacteria were grown in the pilot plant in the Department of Biochemistry with the cooperation and assistance of John C. Garver. The bacteria were grown in 120 liters of medium $A$ at $37 \mathrm{C}$ with vigorous aeration for $5 \mathrm{hr}$. The cells were harvested in a Sharples centrifuge, and an acetone powder of the cell paste was prepared. The acetone powder was stored at $4 \mathrm{C}$ in vacuo over alumina.

General conditions used for enzyme preparations. The following conditions were employed, unless otherwise specified. All operations were conducted at 0 to $5 \mathrm{C}$. Sodium borate buffer $(\mathrm{pH} \mathrm{8.0)}$ of the specified molarity was used routinely. Suspensions $(50 \mathrm{ml})$ of whole cells or of acetone powders were subjected to ultrasonic treatment with a Branson model LS-75 sonifier at maximal power settings for $2.5 \mathrm{~min}$. The temperature of the suspension was maintained below $15 \mathrm{C}$ during sonic treatment. Centrifugations were carried out in a Servall model RC-2 centrifuge at $30,000 \times g$ for $30 \mathrm{~min}$. Fractionations with lithium sulfate were made by the slow addition, with stirring, of the calculated amount ( $w / v)$ of solid lithium sulfate. The resulting suspensions were equilibrated for $30 \mathrm{~min}$ before centrifugation.

Cell-free extracts of whole cells. Cells harvested in the log phase of growth were chilled and collected by centrifugation. The pellet was washed with $0.05 \mathrm{M}$ buffer and resuspended in a volume of buffer equal to four times the wet weight of the cells. The suspension was subjected to ultrasonic treatment, and cellular debris was removed by centrifugation. The supernatant solution was dialyzed against 100 volumes of $0.05 \mathrm{M}$ buffer for $4 \mathrm{hr}$ with buffer changes every 30 min. The solution (cell-free extract) was used immediately or could be stored at $-15 \mathrm{C}$ with no loss in activity.

Extraction and fractionation of acetone powders. A typical enzyme preparation was prepared as follows: $15 \mathrm{~g}$ of acetone powder was suspended in $150 \mathrm{ml}$ of $0.05 \mathrm{M}$ buffer, and the suspension was stirred for $1 \mathrm{hr}$. 
The suspension was subjected to ultrasonic treatment and then centrifuged. The resulting supernatant solution $(120 \mathrm{ml}$; fraction I) was brought to $18 \%$ saturation by the addition of $21.6 \mathrm{~g}$ of solid lithium sulfate. The precipitated protein was removed by centrifugation, and the supernatant solution was brought to $32 \%$ saturation by the further addition of $16.8 \mathrm{~g}$ of lithium sulfate. The precipitate was recovered by centrifugation and was dissolved in $36 \mathrm{ml}$ of $0.05 \mathrm{M}$ buffer $(0.3$ of the original volume). This solution was dialyzed against 2 liters of $0.05 \mathrm{M}$ buffer for $2 \mathrm{hr}$ with buffer changes every $30 \mathrm{~min}$ (fraction II). The enzyme solution was then adjusted to $p \mathrm{H} 4.6$ by the slow addition, with stirring, of $1 \mathrm{~N}$ acetic acid. The suspension was equilibrated for $20 \mathrm{~min}$, and the precipitated protein was removed by centrifugation. The supernatant solution was adjusted to $p \mathrm{H} 8.0$ by the slow addition, with stirring, of $1 \mathrm{~N}$ sodium hydroxide (fraction III). This solution was fractionated with lithium sulfate, and the 15 to $32 \%$ fraction recovered (fraction IV).

Separation of the two transaminases with alumina $C_{\gamma}$. The 15 to $35 \%$ lithium sulfate precipitate (fraction IV) was dissolved in $0.005 \mathrm{M}$ sodium borate buffer $(p H$ 8.0) in a volume equal to 0.35 of that from which it had been precipitated. The solution was dialyzed against 1 liter of the same buffer for $2 \mathrm{hr}$ with buffer changes each $30 \mathrm{~min}$. The enzyme solution was then mixed with a suspension $(48 \mathrm{mg} / \mathrm{ml})$ of alumina $\mathbf{C}_{\gamma}$ (2) such that a final gel-protein ratio of 10:1 was obtained. The $p \mathrm{H}$ of the suspension was adjusted to 6.0 with $0.1 \mathrm{~N}$ acetic acid and was stirred for $20 \mathrm{~min}$. The suspension was clarified by centrifugation, and the supernatant solution was adjusted to $p \mathrm{H} 8.0$ with $1 \mathrm{~N}$ sodium hydroxide and then assayed (gel supernatant solution). The volumes of the respective buffers used to elute the gel in the three subsequent steps were equal to the volume of the gel supernatant solution. In each case, the gel was resuspended in the buffer, stirred for $20 \mathrm{~min}$, and then centrifuged. The molarities of the sodium borate buffer $(p \mathrm{H} \mathrm{8.0)}$ used in the successive elutions of the gel were $0.01 \mathrm{M}, 0.25 \mathrm{M}$, and $0.50 \mathrm{M}$. Each supernatant solution (gel eluate) was assayed.

Standard incubation systems for transaminase assays. The assay for both transaminases was routinely carried out in the forward direction, i.e., the formation of serine or serine-phosphate. The standard incubation system used to measure the hydroxypyruvate transaminase contained: pyridoxal phosphate, $0.03 \mu$ moles; hydroxypyruvate, $25 \mu$ moles; amino acid, $25 \mu$ moles; sodium borate buffer ( $p \mathrm{H} \mathrm{8.0)}, 500 \mu$ moles; ethylenediaminetetraacetate (EDTA), $100 \mu$ moles; enzyme; and double-distilled water to a final volume of $6 \mathrm{ml}$ The reaction mixture employed for hydroxypyruvatephosphate transaminase contained: pyridoxal phosphate, $0.03 \mu$ mole; hydroxypyruvate-phosphate, 5 $\mu$ moles; amino acid, $25 \mu$ moles; sodium borate buffer $(p \mathrm{H}$ 8.0), $500 \mu$ moles; EDTA, $100 \mu$ moles; enzyme (0.1 of that amount used in the assay of hydroxypyruvate transaminase); and double-distilled water to a final volume of $4.0 \mathrm{ml}$. Separate incubation systems containing only the $\alpha$-keto acid or only the amino acid were used as controls for both transaminases. In experiments designed to measure the enzymatic or nonenzymatic recovery of serine or serine-phosphate, these amino acids were added to the above systems in the absence of $\alpha$-keto acid and amino donor, or in the absence of enzyme, respectively. Separate experiments with varying substrate concentrations demonstrated that the above assay conditions were satisfactory. The above conditions were used in all experiments, unless indicated otherwise with a given result.

Incubations were carried out in a water bath at $37 \mathrm{C}$. The enzyme preparation (fraction used is indicated with the individual experiments), pyridoxal phosphate, and amino acid were allowed to equilibrate at $37 \mathrm{C}$ for $10 \mathrm{~min}$. The reaction was then initiated by the addition of the $\alpha$-keto acid and allowed to proceed for $1 \mathrm{hr}$.

Protein was determined by the method of Lowry et al. (12) with bovine serum albumin as the standard. The specific activity of the enzymes is equal to the number of micromoles of product formed per hour under the above conditions per milligram of protein.

Determination of serine-phosphate and serine. Serine-phosphate was converted to serine by hydrolysis with alkaline phosphatase. Serine was determined by the amount of ammonia liberated by periodate oxidation. The details of these methods are described elsewhere (D. A. Walsh and H. J. Sallach, J. Biol. Chem., in press).

Determination of $\alpha$-keto acids. Hydroxypyruvate and $\alpha$-ketoglutarate were measured spectrophotometrically in the presence of $\mathrm{NADH}_{2}$ with D-glycerate dehydrogenase (23) and glutamate dehydrogenase (D. A. Walsh and H. J. Sallach, J. Biol. Chem., in press), respectively.

Growth of strain $S / G$ on the product of hydroxypyruvate transamination. In these experiments, hydroxypyruvate and glutamate were incubated in the standard incubation system with $25 \mathrm{mg}$ of enzyme (fraction III) for $1 \mathrm{hr}$. The reaction was stopped by placing the tubes in a boiling-water bath for 5 min. A complete system stopped at zero-time was used as the control. Denatured protein was removed by centrifugation, and concentrated Davis minimal media and glucose were added to the supernatant solutions to bring them to the normal concentration of salts and glucose in the Davis medium. The samples were sterilized by filtration through a membrane-filter apparatus (Millipore) and were inoculated with strain $\mathrm{S} / \mathrm{G}$. The increase in turbidity was followed for $24 \mathrm{hr}$.

Uptake of radioactive hydroxypyruvate and L-serine by strain $S$. For this experiment, cells of strain $\mathbf{S}$ were grown at $25 \mathrm{C}$ in Davis medium supplemented with serine and adjusted to $p \mathrm{H} 6.5$. A $100-\mathrm{ml}$ subculture was harvested in early log phase, washed, and resuspended in the above medium, but without serine. The bacteria were then incubated for $30 \mathrm{~min}$, centrifuged, and resuspended in $15 \mathrm{ml}$ of the same medium. This suspension was used to inoculate four parallel cultures. Two cultures (5-ml volume) were used to follow the uptake of radioactive hydroxypyruvate or L-serine. The other two cultures (20-ml volume) were used to follow the growth of the bacteria on these 
compounds. Both sets of cultures contained 3.2 $\mu \mathrm{moles} / \mathrm{ml}$ of either hydroxypyruvate or L-serine. OD readings and samples for the determination of radioactivity were taken at the time intervals noted in the text. To measure uptake, the bacterial cells were separated from the culture fluid by filtration through membrane filters and were washed with ice-cold salts solution. The filters were dried, mounted on aluminum planchets, and counted with a microthin window gasflow counter operated in the Geiger region. The specific activity of both $\mathrm{C}^{14}$-serine and $\mathrm{C}^{14}$-hydroxypyruvate was 64,000 counts per min per $\mu$ mole.

Heat inactivation. In these experiments, the enzyme (fraction II) was dissolved in $0.05 \mathrm{M}$ sodium borate buffer ( $p \mathrm{H} 8.0)$. The enzyme solution $(20 \mathrm{ml})$ was added to a 125-ml Erlenmeyer flask in a water bath maintained at $65 \mathrm{C}$. The flask and contents were gently swirled to insure uniform heating. Samples, taken at the time intervals indicated in the text, were cooled rapidly in an ice-salt bath. Denatured protein was removed by centrifugation, and the supernatant solutions were assayed for transaminase activities.

\section{Results}

Quantitative data for the biosynthesis of serine from hydroxypyruvate and various amino acids in cell-free extracts of $E$. coli $\mathrm{K}-12$ grown on glucose salts medium are presented in Table 1. Individual control experiments were carried out with each amino acid in the absence of hydroxypyruvate. In no case was serine formation observed with the amino acids alone. Since Lglutamate was the most active amino group donor of those investigated, it was used in subsequent studies. Additional experiments demonstrated that both hydroxypyruvate and L-glutamate were required for serine biosynthesis. No significant amount of serine was formed with either substrate alone, as measured by the periodate method. Samples of reaction mixtures were subjected to paper chromatography and to analyses on the Beckman-Spinco amino acid analyzer. The results of these studies confirmed the fact that serine was the product formed in the complete incubation system. The values obtained for serine production with the amino acid analyzer and by the periodate method were in good agreement, and, therefore, the latter method was used in subsequent studies.

If the reaction observed is one of transamination, equimolar amounts of serine and $\alpha$-ketoglutarate should be formed. This result was obtained (Table 2). In separate experiments, it was established that the reaction is proportional to the amount of enzyme used in the incubation system.

Since it has been shown that D-amino acids undergo transamination reactions in microorganisms (13), the activities of the D- and L-isomers were compared in this system. Neither D-glutamate nor D-alanine participated in the transamination reaction to any significant extent. As further proof that the product of the transamination reaction was $\mathrm{L}$-serine, the ability of the enzymatic product to support the growth of the serine auxotroph, strain $\mathrm{S} / \mathrm{G}$, was investigated. Bacterial growth in samples prepared as described in Materials and Methods was followed for $24 \mathrm{hr}$. The sample from the incubation (1 hr) that contained both hydroxypyruvate and L-glutamate as substrates supported the growth of the auxotroph. No growth was obtained with the zero-time control sample. These results establish that the serine formed in the transamination reaction is of the $\mathbf{L}$-configuration.

TABLE 1. Serine formation by transamination of hydroxypyruvate with various amino acids ${ }^{a}$

\begin{tabular}{|c|c|}
\hline Amino acid added & Total serine formed \\
\hline & $\mu$ moles \\
\hline L-Glutamate $\ldots \ldots \ldots \ldots$ & 6.5 \\
\hline L-Alanine $\ldots \ldots \ldots \ldots$ & 4.4 \\
\hline L-Aspartate $\ldots \ldots \ldots \ldots$ & 2.0 \\
\hline Glycine ............ & $<0.2$ \\
\hline
\end{tabular}

${ }^{a}$ Enzyme $=15.7 \mathrm{mg}$ of protein, cell-free extract.

TABLE 2. Equivalence of product formation in the transamination reaction $^{a}$

\begin{tabular}{l|l|l}
\hline \multirow{2}{*}{ Reactants } & \multicolumn{2}{|c}{ Products } \\
\cline { 2 - 3 } & Serine & $\begin{array}{l}\alpha \text {-Keto- } \\
\text { glutarate }\end{array}$ \\
\cline { 1 - 3 } & $\mu$ moles & $\mu$ moles \\
Hydroxypyruvate alone........ & 0.4 & 0 \\
Glutamate alone............... & 0 & 0.3 \\
Glutamate + hydroxypyruvate. & 4.7 & 4.2 \\
\hline
\end{tabular}

a Enzyme $=17.3 \mathrm{mg}$ of protein, fraction III.

The reverse reaction has not been studied in detail. Glutamate and alanine have been identified as the respective products of the transamination of serine with $\alpha$-ketoglutarate or pyruvate by chromatography of reaction mixtures on the amino acid analyzer. Hydroxypyruvate was established as the other product of the reaction by spectrophotometric assays with $\mathrm{NADH}_{2}$ and spinach D-glycerate dehydrogenase. Under comparable incubation conditions, product formation in the reverse direction is much less than that of the forward reaction, i.e., serine biosynthesis.

As had been demonstrated earlier in other laboratories $(15,20)$, there is a very active hydroxypyruvate-phosphate transaminase in ex- 
tracts of $E$. coli $\mathrm{K}-12$. The level of activity of this transaminase in crude extracts is approximately 10-fold greater than that of the hydroxypyruvate transaminase (Table 3 ). It was found that the transamination of hydroxypyruvate, but not hydroxypyruvate-phosphate, is inhibited by inorganic phosphate (Table 4). This observation led to experiments designed to determine

TABLE 3. Comparison of the levels of activity of the two transaminases

\begin{tabular}{|c|c|c|}
\hline \multirow{2}{*}{ Reactants } & \multicolumn{2}{|c|}{$\begin{array}{l}\text { Amino acids pres- } \\
\text { ent at termina- } \\
\text { tion of reaction }\end{array}$} \\
\hline & Serine-P & Serine \\
\hline & umoles & $\mu$ moles \\
\hline Experiment I ${ }^{a}$ & & \\
\hline Glutamate alone. . & 0 & - \\
\hline Hydroxypyruvate-P alone. . & 0 & - \\
\hline Glutamate + hydroxypyruvate-P.. & 3.0 & - \\
\hline $\begin{array}{l}\text { Control with added serine-P }(5 \\
\mu \text { moles) and no substrates....... }\end{array}$ & 4.0 & - \\
\hline $\begin{array}{l}\text { Control with added serine-P }(5 \\
\mu \text { moles) and no enzyme } \ldots \ldots \ldots\end{array}$ & 4.8 & 一 \\
\hline Experiment $\mathrm{II}^{b}$ & & \\
\hline Glutamate alone $\ldots \ldots \ldots \ldots \ldots$ & - & 0 \\
\hline Glutamate + hydroxypuruvate... & 一 & 3.2 \\
\hline $\begin{array}{c}\text { Control with added serine }(5 \\
\mu \text { moles }) \text { and no substrates....... }\end{array}$ & 一 & 4.1 \\
\hline $\begin{array}{c}\text { Control with added serine }(5 \\
\mu \text { moles }) \text { and no enzyme } \ldots \ldots \ldots\end{array}$ & - & 4.8 \\
\hline
\end{tabular}

${ }^{a}$ Enzyme $=2.85 \mathrm{mg}$ of protein, fraction $\mathrm{I}$.

${ }^{b}$ Enzyme $=28.5 \mathrm{mg}$ of protein, fraction $\mathrm{I}$.

TABLE 4. Inhibition studies with inorganic salts

\begin{tabular}{|c|c|c|}
\hline Reactants & $\underset{\text { salt }^{a}}{\text { Inorganic }}$ & $\begin{array}{l}\text { Per cent } \\
\text { activity }\end{array}$ \\
\hline$\underset{\text { pyruvate }}{\text { Glutamate }}+\ldots \ldots \ldots \ldots \ldots$ & $\begin{array}{l}\mathrm{None} \\
\mathrm{KH}_{2} \mathrm{PO}_{4} \\
\mathrm{NaH}_{2} \mathrm{PO}_{4} \\
\mathrm{~K}_{2} \mathrm{SO}_{4} \\
\mathrm{Na}_{2} \mathrm{SO}_{4} \\
\mathrm{KCl} \\
\mathrm{NaCl}\end{array}$ & $\begin{array}{r}100 \\
58 \\
56 \\
84 \\
87 \\
100 \\
100\end{array}$ \\
\hline $\begin{array}{c}\text { Glutamate }+ \text { hydroxy- } \\
\text { pyruvate-phosphate }{ }^{c} \ldots \ldots\end{array}$ & $\begin{array}{l}\text { None } \\
\mathrm{KH}_{2} \mathrm{PO}_{4}\end{array}$ & $\begin{array}{l}100 \\
100\end{array}$ \\
\hline
\end{tabular}

a The amount used was $10 \mu$ moles per incubation.

${ }^{b}$ Enzyme in this series $=15.5 \mathrm{mg}$ of protein, fraction $I$.

${ }^{c}$ Enzyme in this series $=1.55 \mathrm{mg}$ of protein, fraction $I$. whether the concentration of inorganic phosphate in the growth medium might affect the level of the hydroxypyruvate transaminase in the bacteria. For these experiments, bacteria were grown in high or low phosphate media, and cell-free extracts were prepared as described in Materials and Methods. No marked differences in the levels of activity of either transaminase were noted under the two different growth conditions. Similar results were obtained in experiments in which bacteria were grown on Davis minimal medium with fructose replacing glucose as the carbon source.

Hydroxypyruvate transaminase has been demonstrated in extracts of the mutant strains $S$ and S/G. The relative levels of activity of this transaminase and of hydroxypyruvate-phosphate transaminase are essentially the same as those found in strain K-12. Different growth conditions were investigated. Replacement of glucose by fructose did not result in a marked difference in the activity of hydroxypyruvate transaminase in strain $\mathrm{S}$. The same result was obtained with strain $\mathrm{S} / \mathrm{G}$ grown on glucose or fructose supplemented with either glycine or serine.

In confirmation of the observations of Pizer (16), it was found that strains S and S/G do not grow when the serine or glycine is replaced by equimolar amounts of D-glycerate or hydroxypyruvate. Although the levels of hydroxypyruvate transaminase are relatively low, the lack of at least limited growth on hydroxypyruvate was unexpected. Therefore, experiments were carried out to determine whether the bacteria were capable of accumulating this compound. The uptake of radioactive hydroxypyruvate into cells of strain $\mathrm{S}$ was compared to that of $\mathrm{C}^{14}$-L-serine by the procedures described in Materials and Methods. The data (Table 5) indicate that very little hydroxypyruvate enters the cells. Uptake of serine, on the other hand, is quite rapid. The slight increase in OD of the culture containing hydroxypyruvate does, however, parallel the limited incorporation of radioactivity observed. If hydroxypyruvate can only enter the cells by the process of passive diffusion, then the cells will only become isotonic with the medium with respect to this compound. In early log phase $\left(\mathrm{OD}_{650}=0.3\right)$, the bacterial cells will constitute about 0.001 of the volume of a $1-\mathrm{ml}$ suspension. At equilibrium, the cells in this amount of suspension will contain approximately $0.1 \%$ of the hydroxypyruvate added to the medium, i.e., 3.2 $\times 10^{-3} \mu$ mole. This result was observed. Therefore, the failure of the mutant strain to grow on hydroxypyruvate can be explained by the inability of the cells to accumulate this compound actively. 
TABLE 5. Uptake of radioactive hydroxypyruvate and $L$-serine by Escherichia coli strain $S$

\begin{tabular}{|c|c|c|c|c|}
\hline Compound & $\begin{array}{c}\text { Time } \\
\text { of sam- } \\
\text { pling }\end{array}$ & $\begin{array}{l}\text { Radio- } \\
\text { activity } \\
\text { of cells }\end{array}$ & $\begin{array}{c}\text { Calcu- } \\
\text { lated } \\
\text { uptake } \\
\text { (umoles } \\
\left.\times 10^{2}\right)\end{array}$ & $O D_{\text {GSO }}$ \\
\hline & $\min$ & count/min & & \\
\hline $\mathbf{C}^{14}$-L-serine ${ }^{a} \ldots \ldots$ & $\begin{array}{c}0 \\
40 \\
80 \\
140 \\
330\end{array}$ & $\begin{array}{r}4,757 \\
15,950 \\
19,271 \\
20,637 \\
28,077\end{array}$ & $\begin{array}{r}74 \\
249 \\
301 \\
322 \\
439\end{array}$ & $\begin{array}{l}0.29 \\
0.31 \\
0.35 \\
0.42 \\
0.69\end{array}$ \\
\hline $\begin{array}{l}\text { C14-hydroxypy ru- } \\
\text { vate }^{a} \ldots \ldots \ldots \ldots \ldots\end{array}$ & $\begin{array}{r}0 \\
40 \\
80 \\
140 \\
330\end{array}$ & $\begin{array}{r}0 \\
82 \\
175 \\
171 \\
212 \\
\end{array}$ & $\begin{array}{l}0 \\
1.3 \\
2.7 \\
2.7 \\
3.3\end{array}$ & $\begin{array}{l}0.26 \\
0.26 \\
0.27 \\
0.28 \\
0.31\end{array}$ \\
\hline
\end{tabular}

a Specific activity $=64,000$ counts per min per $\mu$ mole.

The question as to whether the lower activity observed with hydroxypyruvate, as compared with that with hydroxypyruvate-phosphate, represents the action of the same enzyme on two different substrates was an obvious point to be considered. The effect of heat on the two activities was investigated (Fig. 1). The marked lability of the activity with hydroxypyruvate-phosphate and the marked stability of that with hydroxypyruvate are indicative that two different enzymes are involved.

Preliminary studies on the fractionation of extracts with lithium sulfate led to changes in the ratio of the two activities, but no complete separation was achieved by this procedure. This observation was a further indication that separate enzymes were participating in the two reactions. A complete separation of the two transaminases was achieved by the use of alumina $\mathrm{C} \gamma$ (Table 6). Hydroxypyruvate-phosphate transaminase, but not hydroxypyruvate transaminase, is adsorbed on the gel at $p \mathrm{H} 6.0$, under the conditions described in Materials and Methods. Both transaminases at this state have been purified approximately 10-fold, relative to the acetone powder extracts. Preliminary studies showed that an additional twofold purification of the hydroxypyruvate transaminase can be achieved by heat treatment of gel supernatant fraction at $65 \mathrm{C}$.

In view of the structural similarity of the $\alpha$ keto acids that are substrates for the two transaminases, it was of interest to determine whether the substrate for one transaminase would inhibit the activity of the other enzyme (Table 7). No

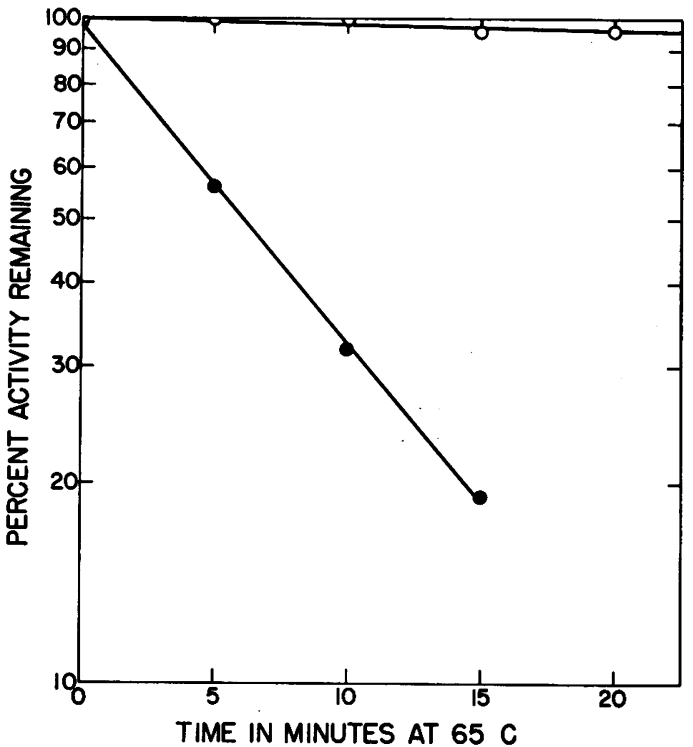

FIG. 1. Effect of heat on the activities of hydroxypyruvate-L-glutamate (O) and hydroxypyruvatephosphate-L-glutamate (O) transaminases.

TABLE 6. Separation of two transaminases with alumina $C_{\gamma}$

\begin{tabular}{|c|c|c|c|c|}
\hline \multirow{2}{*}{ Enzyme prepn } & \multicolumn{2}{|c|}{$\begin{array}{l}\text { Hydroxypyru- } \\
\text { vate transami- } \\
\text { nase }\end{array}$} & \multicolumn{2}{|c|}{$\begin{array}{l}\text { Hydroxypyru- } \\
\text { vate-P } \\
\text { transaminase }\end{array}$} \\
\hline & $\begin{array}{c}\text { Specific } \\
\text { activ- } \\
\text { ity }\end{array}$ & $\begin{array}{l}\text { Total } \\
\text { activ- } \\
\text { ity }\end{array}$ & $\begin{array}{c}\text { Specific } \\
\text { activ- } \\
\text { ity }\end{array}$ & $\begin{array}{l}\text { Total } \\
\text { activ- } \\
\text { ity }\end{array}$ \\
\hline Fraction IV. $\ldots \ldots \ldots$ & 0.4 & $\begin{array}{r}\% \\
100\end{array}$ & 3.5 & $\begin{array}{r}\% \\
100\end{array}$ \\
\hline $\begin{array}{l}\text { Gel supernatant frac- } \\
\text { tion } . \ldots \ldots \ldots \ldots \ldots\end{array}$ & 1.1 & 87 & 0 & 0 \\
\hline $\begin{array}{c}\text { Gel eluate, } 0.01 \quad \text { м } \\
\text { buffer................ }\end{array}$ & $\mathbf{0}$ & 0 & 0 & $\mathbf{0}$ \\
\hline $\begin{array}{c}\text { Gel eluate, } 0.25 \mathrm{M} \\
\text { buffer............... }\end{array}$ & $\mathbf{0}$ & $\mathbf{0}$ & $\mathbf{0}$ & $\mathbf{0}$ \\
\hline $\begin{array}{c}\text { Gel eluate, } 0.50 \mathrm{~m} \\
\text { buffer.............. }\end{array}$ & 0 & 0 & 12.7 & 90 \\
\hline
\end{tabular}

a Expressed as $\mu$ moles of serine per hour per milligram of protein.

${ }^{b}$ Expressed as $\mu$ moles of serine-phosphate per hour per milligram of protein.

significant inhibition was observed in the activity of either transaminase.

\section{Discussion}

The biochemical and genetic evidence that the mutational loss of phosphoglycerate dehydrogenase results in a growth requirement for L-serine clearly establishes that the phosphorylated pathway for serine biosynthesis is the 
TABLE 7. Studies with the separated transaminases

\begin{tabular}{|c|c|c|}
\hline \multirow{2}{*}{ Reactants in addition to L-glutamate } & \multicolumn{2}{|c|}{$\begin{array}{l}\text { Amino acids pre- } \\
\text { sent at termina- } \\
\text { tion of reaction }\end{array}$} \\
\hline & Serine & $\begin{array}{l}\text { Serine- } \\
\text { phos- } \\
\text { phate }\end{array}$ \\
\hline & umoles & umoles \\
\hline I. Hydroxypyruvate transaminase ${ }^{a}$ & & \\
\hline Hydroxypyruvate-P. . . . . . . . . . & 0 & 0 \\
\hline 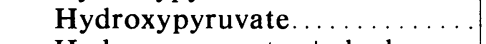 & 3.1 & 一 \\
\hline $\begin{array}{l}\text { Hydroxypyruvate }+ \text { hydroxy- } \\
\text { pyruvate-P }(5 \mu \text { moles }) \ldots \ldots \ldots\end{array}$ & 2.9 & \\
\hline $\begin{array}{l}\text { Hydroxypyruvate }+ \text { hydroxy }- \\
\text { pyruvate-P }(10 \mu \text { moles }) \ldots \ldots\end{array}$ & 2.9 & 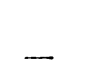 \\
\hline $\begin{array}{r}\text { Hydroxypyruvate }+\mathrm{KH}_{2} \mathrm{PO}_{4} \\
(10 \mu \text { moles }) \ldots \ldots \ldots \ldots\end{array}$ & 1.1 & \\
\hline $\begin{array}{l}\text { II. Hydroxypyruvate-P transam- } \\
\text { inase }^{b}\end{array}$ & & \\
\hline Hydroxypyruvate... & 0 & 0 \\
\hline Hydroxypyruvate-P . . . . . . & - & 4.5 \\
\hline $\begin{array}{l}\text { Hydroxypyruvate- } P+\text { hydroxy }- \\
\text { pyruvate }(5 \mu \text { moles }) \ldots \ldots \ldots\end{array}$ & - & 4.5 \\
\hline Hydroxypyruvate-P + hydroxy- & & \\
\hline pyruvate $(10 \mu$ moles $) .. . \ldots \ldots$ & - & 4.2 \\
\hline $\begin{array}{l}\text { Hydroxypyruvate- } \mathrm{P}+\mathrm{KH}_{2} \mathrm{PO}_{4} \\
(10 \mu \text { moles }) \ldots \ldots \ldots \ldots \ldots\end{array}$ & - & 4.2 \\
\hline
\end{tabular}

${ }^{a}$ Enzyme $=2.4 \mathrm{mg}$ of protein, gel supernatant solution.

${ }^{b}$ Enzyme $=0.3 \mathrm{mg}$ of protein, gel eluate.

major one in E. coli (20). On the other hand, the present studies have demonstrated that extracts of this organism catalyze the formation of L-serine from hydroxypyruvate via a transamination reaction with L-glutamate. Furthermore, the results show that the enzyme catalyzing this reaction is different from the transaminase carrying out a similar reaction with hydroxypyruvate-phosphate. Hence, at least one enzyme of the nonphosphorylated pathway for serine biosynthesis is present in low levels in $E$. coli. However, even a minor role for hydroxypyruvate transaminase in serine metabolism would be dependent upon a metabolic source of its $\alpha$-keto substrate. D-Glycerate is a precursor of hydroxypyruvate in plant (19) and animal (21) systems. The brief report of Smith et al. (Bacteriol. Proc., p. 107, 1956) suggests that such a reaction occurs in $E$. coli, Crook's strain. $\alpha$-Keto- $\beta$-hydroxy acid reductase, an enzyme involved in valine and isoleucine biosynthesis, has been purified from $E$. coli (17) and has been shown to catalyze the oxidation of reduced nicotinamide adenine dinucleotide phosphate in the presence of hydroxypyruvate, as well as with the intermediates in the valine and isoleucine pathways. Hydroxypyruvate-phosphate, through the action of a phosphatase, is another possible precursor of hydroxypyruvate. Additional studies are required to determine whether this compound is formed in bacterial systems and to assess any physiological role for the hydroxypyruvate-L-glutamate transaminase in $E$. coli.

\section{ACKNOWLEDGMENTS}

This investigation was supported by Public Health Service grant no. AM-00922 from the National Institute of Arthritis and Metabolic Diseases.

We thank S. Simmonds of Yale University for making available to us the $E$. coli mutants, strain $S$ and S/G. We are indebted to John C. Garver, Department of Biochemistry, for his cooperation and assistance in growing the bacteria in the pilot plant. The technical assistance of E. H. Kmiotek is gratefully acknowledged.

\section{Literature Cited}

1. Ballou, C. E. 1960 . Hydroxypyruvic acid phosphate, p. 66-68. In H. A. Lardy [ed.], Biochemical preparations, vol. 7. John Wiley \& Sons, Inc., New York.

2. Colowick, S. P. 1955. Separation of proteins by use of adsorbents, p. 90-98. In S. P. Colowick and N. O. Kaplan [ed.], Methods in enzymology, vol. 1. Academic Press, Inc., New York.

3. Davis, B. D., AND E. Mingioli. 1950. Mutants of Escherichia coli requiring methionine or vitamin $B_{12}$. J. Bacteriol. 60:17-28.

4. Dickens, F., and D. H. Williamson. 1958. The preparation and properties of lithium hydroxypyruvate and hydroxypyruvic acid. Biochem. J. 68:74-84.

5. Garen, A., And C. Levinthal. 1960. A finestructure genetic and chemical study of the enzyme alkaline phosphatase of $E$. coli. I. Purification and characterization of alkaline phosphatase. Biochim. Biophys. Acta 38: $470-483$.

6. HANFORD, J., AND D. D. DAviES. 1958. Formation of phosphoserine from 3-phosphoglycerate in higher plants. Nature 182:532-533.

7. Hedrick, J. L., AND H. J. SAllaCH. 1961. The metabolism of hydroxypyruvate. I. The nonenzymatic decarboxylation and autoxidation of hydroxypyruvate. J. Biol. Chem. 236:1867-1871.

8. Holzer, H., AND A. Holldorf. 1957. Isolierung von D-glycerat-dehydrogenase, einige eigenschaften des enzyms und seine verwendung zur enzymatisch-optischen bestimmung von hydroxypyruvat neben pyruvat. Biochem. Z. 329: 292-312.

9. IChihara, A., AND D. M. Greenberg. 1957. Further studies on the pathway of serine formation from carbohydrate. J. Biol. Chem. 224:331-340.

10. LaRge, P. J., AND J. R. QuAYLe. 1963. Microbial growth on $\mathrm{C}_{1}$ compounds. Enzyme activities in extracts of Pseudomonas AM 1. Biochem. J. 87:386-396.

11. Levine, E. M., AND S. Simmonds. 1960. Metabolite 
uptake by serine-glycine auxotrophs of Escherichia coli. J. Biol. Chem. 235:2902-2909.

12. Lowry, O. H., N. J. Rosebrough, A. J. Farr, AND R. J. RANDALl. 1951. Protein measurement with the Folin phenol reagent. J. Biol. Chem. 193:265-275.

13. Meister, A. 1965. Biochemistry of the amino acids, 2nd ed., vol. 1, p. 357-358. Academic Press, Inc., New York.

14. Neuhaus, F. C., and S. Korkes. 1958. Phosphoserine, p. 75-79. In C. S. Vestling [ed.], Biochemical preparations, vol. 6. John Wiley \& Sons, Inc., New York.

15. Pizer, L. I. 1963. The pathway and control of serine synthesis in Escherichia coli. J. Biol. Chem. 238:3934-3944.

16. Pizer, L. I., AND M. L. Potochny. 1964. Nutritional and regulatory aspects of serine metabolism in Escherichia coli. J. Bacteriol. 88:611619.

17. Radhakrishnan, A. N., R. P. Wagner, AND E. E. SNELl. 1960. Biosynthesis of valine and isoleucine. III. $\alpha$-Keto- $\alpha$-hydroxy acid reduc- tase and $\alpha$-hydroxy- $\beta$-keto acid reductoisomerase. J. Biol. Chem. 235:2322-2331.

18. Sallach, H. J. 1956. Formation of serine from hydroxypyruvate and L-alanine. J. Biol. Chem. 223:1101-1108.

19. Stafford, H. A., A. Magaldi, and B. VennesLAND. 1954. The enzymatic reduction of hydroxypyruvic acid to D-glyceric acid in higher plants. J. Biol. Chem. 207:621-629.

20. UMBARger, H. E., M. A. UMBARGER, AND P. M. L. SIU. 1963. Biosynthesis of serine in Escherichia coli and Salmonella typhimurium. J. Bacteriol. 85:1431-1439.

21. Walsh, D. A., and H. J. Sallach. 1965. Purification and properties of chicken liver D-3-phosphoglycerate dehydrogenase. Biochemistry 4: 1076-1085.

22. Willis, J. E., and H. J. Sallach. 1962. Evidence for a mammalian D-glycerate dehydrogenase. $J$. Biol. Chem. 237:910-915.

23. Willis, J. E., and H. J. Sallach. 1963. Serine biosynthesis from hydroxypyruvate in plants. Phytochemistry 2:23-28. 